\title{
INVESTIGATING FACTORS AFFECTING THE FORMATION OF INFORMAL SETTLEMENTS IN IRAN
}

\author{
Pedram Amiri \\ Department of Geography and urban planning, Humanities Faculty, Islamic Azad University, \\ Kermanshah, Iran \\ Nowzar Ghanbari \\ Department of Geography and urban planning, Humanities Faculty, Islamic Azad University, \\ Kermanshah, Iran
}

\begin{abstract}
The consequence of rapid urbanization expansion in Iran, is the emergence of large cities and marginalized areas with abnormal housing and disorganized tissue. The main reasons for the formation of squatters in Tehran have been investigated in this study. Present study seeks to determine factors affecting the formation of the marginalizing using identify the situation of marginalized. Method of this study is documentation and survey method using a questionnaire. Conceptual and theoretical aspects have been examined using document method and survey method has been used to investigate the way of distribution and relations between dependent and independent variables. Sampling method is a quota in which questionnaires were distributed 200 households randomly. Independent variables include immigration, low income; high rent of housing and easier access to shelter and dependent variable of suburbanization. In the survey, after data collection using questionnaire and data processing with SPSS software, descriptive method and inferential statistics of chi-square has been used according to the level of variables measurement. Obtained results of the study indicate there is a relationship between attractions factor of Tehran and push factor of prior place of living with suburbanization
\end{abstract}

Keywords: suburbanization, Tehran, immigration, income, housing

\section{INTRODUCTION}

Suburbanization and informal settlement is a phenomenon that has emerged following structural changes and socio-economic problems such as rapid flow of urbanization and unbridled rural migration in most countries, especially Third world countries. This urban problem is not merely a physical question and arises from macro structure factor in national and regional levels. The explosive growth of urban population has surpassed from capability of governmental and nongovernmental organizations to develop and deliver urban services and facilities for this growing population. The housing and shelter needs of low-income families, which are not being met in formal and scheduled atmosphere of the city has expanded marginalizing unprecedentedly (Hadizadeh Bazar.7.2003)

One of the most striking aspects of migration (especially migration from rural to urban) in Iran, like many developing countries was physical and spatial face of this flow of immigration that has been emerged in form of suburbanization .In fact, suburbanization is the employment of immigrants margin by which never their wages effort the adequacy of a minimum living within the city (Hesamian et al 112:2009) suburbanization can be considered as a living in urban space that in all aspects of political, social, cultural, economic, physical and legal with other types of living in city indicate fundamental differences (coit,1994:116) In most cities of Iran, especially in metropolitans there is a phenomenon of informal settlements that is increasing day by day. This population centers from one side has multiple cultural, social, economic, physical, security, infrastructure problems and on the other hand have emerged several problems for metropolitans. As far as one can say today periphery of cities has jeopardized metropolitan's life areas as well as. Tehran meanwhile is obvious example of a rising 
trend of suburbanization in recent decades that has been enclosed in a belt of urban poverty. Regarding different effective reasons and factors in growth and development of suburbanization in Tehran, intellectual contemplation on the whole internal and external factors affecting the growth margin of Tehran has been changed to investigate this article. The present research seeks to identify affecting factors on forming suburbanization using the marginalized situation in Tehran and can improve its process to empower them with respect to the environmental, economic, social and cultural abilities using providing appropriate methods for get rid of these problems.

\section{THEORETICAL FOUNDATIONS}

\section{THE CONCEPT OF SUBURBANIZATION OR INFORMAL SETTLEMENTS}

Margin encompasses a wide range of conceptual examples that generally point to type and style of life of a group of social actors. In some resources and countries, the term Slum (or shacks) is applied as synonymous of the margins. Britannica Encyclopedia refers slum to the residential area, which has tendency to decay in physical and social terms and no satisfaction cannot be seen. Poor housing conditions, inadequate lighting, public toilets and inappropriate baths is its feature. Sarah Fly and colleagues from the "Report of Child Health at the fringes of cities in Asia and the Near East» have defined slum to a rented, old, worn out and picks building which sometimes rented several families (Fly \& others, 2005: 23). Development of slums in big cities, especially in large cities of the Third World, is one of the most important issues of the city. The growth of slums and efforts to improve the living conditions of its inhabitants is one of the most important concerns of urban management. Different methods have been thought to solve this problem and have applied in some cases (Saeidnia, 2004: 105) Informal settlement in our country has been faced growing faster than the growth of urbanization and in fact informal settlements is one of the prominent figures of urban poverty that forms inside or beside of the cities without building permits and urbanism informal planning with the accumulation of low-income people low level of quantity and quality of life. Suburbanization in broad sense includes those who in and habit within the city's economy but are not attracted to the city's economy. Urban attractions and urban prosperity uprooted these people from their homeland and draw them to the industrial centers of the labor market. Suburbanization has been also called in specialized texts sciences related to society and the city, with other titles such as informal settlements, Auto settlement, abnormal and dysfunctional settlement, unjust settlement, shacks and slums. informal settlements is the type of settlement in special place that people living in , are in different conditions filled with life's problems and solving problems requires special attention and planning. Suburbanization in its physical concept concludes erected quick shelters on land owned by others located in the suburbs of cities. so there is not true concept for all cases seen in the Third World. Anomalous housing, homes established overnight or suburbanization are all used interchangeably. General characteristics of this style of residence in Iran are as follows: auto and illegal construction, Failure to observe the technical principles and standards, negligible utilization of services, low level of needed applications, existence of low-income groups, informal employment and widespread unemployment, lack of compatibility with the rest of the city and lack of monitoring them(Rahnama and Tavangar,88.2008) The so-called informal settlement is synonymous with land seizure by a person without land ownership that resides in that. This characteristic is distinction between informal settlements host ofwith other settlements, displaced aggression specifies that these settlements are some forma illegal use of land, because seizure is unfound to have implications on land ownership to no rent is not paid to their rightful owners. "(Macedo, 2000: 11)

It is noteworthy that seizure land to establish informal settlements is into three groups: organized aggression, division of land into smaller pieces with the permission of the owner and seizing of the land buyer (Piran101:1994). Urban slums are like Ghettoes of poverty, the status of those human groups that urban society and organizations governing it still is indifferent towards its acceptance as citizens. It seems that a generation must be sacrificed and destroy life on the fringes of cities So the next generation can adapt themselves with Urban population (Shakuie, 1986: 20). Therefore, the informal settlements can be defined a residential area that has been developed without legal demand for land or without authorization from the authorities responsible for manufacturing in a way that their infrastructures and urban services in these areas is unsuitable due to illegal or quasi-legal status (Srivinas, 2004: 2). In other words, it can be said Aquarts or Zoorabad settlements, a residential area 
that is occupied without illegal permission from the authorities and results from spontaneous response to the housing needs of people with low income (Sarrafi, 65:2002)

\section{PERSPECTIVES RELATED TO SUBURBANIZATION}

Many opinions and perspectives have been provided in relation to the squatter phenomenon so far by the experts such as Lewis combined theory with regard to the socio-ethnic links(Papli Yazdi and Rajabi310:2004) Louis Wirth urbanization and spatial segregation theory (ibid., 306), Ecological theories of the Chicago School, Robert Park views about the relationship between affordable residential areas and suburbanization (Momtaz 2004: 128). Claude Grown theory about changes in utilization of land and lack of housing in marginalized areas(khoobayand,48:2005)and the school of dependence and Roushtayn immigration laws based on the migration of people without access to urban opportunities (Oberoi, 1991: 70). The following are some unknown point of view.

Ecological perspective: some researchers have looked at the issue of Suburbanization from urban ecology perspective and have tried to pay attention to physical texture of the mechanisms of emergence of Suburbanization(Zahed Zahedani,13:2001) This view is based on Chicago school, analyzes the city as a place of the struggle for survival and more appropriate locating in the best urban space. These scholars consider migration from rural and urban environments and creating marginal areas as the most important factors in connection with the formation suburbanization. They say as the speed of population spatial mobility increase, and rate of migration has been increased, the immigration is expressed as incorrect social phenomenon and it is more correct to talk about it as a social problem( Taghavi11.2008) Park pointed to the cultural and ethnic conflicts arising from migration, considers this phenomenon as one of the reasons for the realization of suburbanization(Rabbani et al94:2006) In fact, Park (1967) investigate migration and slum from the perspective of social disorganization as a consequence of the dominance of the industry, high levels of social mobility and high population density and believe that such changes within metropolises develop the values and delinquent and criminal of the traditions .In fact, immigrants have their first experience the presence in origin with economic, social, cultural and environmental differences(Findeli82:1993). With the migration to outlying areas of the city not only the location of people's lives will change, their social status, man and society will changed (Khabbaz Beheshti, 1380: $45)$.

Liberal attitude: Liberal attitude contains a collection of John $f$ turner theory (Prian96:1994) In this view the squatter phenomenon as an accepted fact and seeks the ways and solutions to optimize living conditions and are living in marginalized areas(Sheikhi30.2001). Most liberal economists considered rural to urban migration as desirable economic development process and thought that internal migration is a natural process up to force extra work to gradually meet industry growth and development from rural sector and meet industry development. Thus, they knew it socially beneficial. But the result was followed rapid urbanization growth and metropolises heterogeneity. Therefore, liberal economists' views were changed and consider immigration as aggravating factors of urban unemployment that in fact, shift rural poverty to urban poverty with all its deprivations (Todaro, 1987: 381).

Poverty culture point of view : Poverty culture point of view firstly has been presented in 1959 by Oscar Lewis (Shebani.44:2005) He believed that poor people have decadent and backward values, which they transmitted to their children(22:Lewis: 1982). As a result, they insist the insistence on living in slums and shantytowns and do not accept the developed form of life in terms of economicsocial and political form and are against that(Athari30:2002) According to Lewis (1998) suburbanization associated with the culture of poverty and residents of the areas that most of them are immigrants, and in terms of ethnic background and restrictions in social mobility and low economic and social base that they have, they are different with other resident of urban area. In general, the view supports the idea that poor people are poor because they are poor and food and education of the poor kids is bad and inappripoirate and they learner their culture from their families and elders to accept the poverty as an inevitable issue (Fakoohi196:2004 and Gilbert and Galker 192:1996) 


\section{DETERMINE HISTORY OF THE SUBURBANIZATION IN IRAN}

The start of marginalization in third world countries has been happened with not-so-short delay and took broader dimension due to weak management and limitation of financial resources(Hataminejad and Zomorodian 25:2002) Suburbanization in today's concept is alter ego of alter ego in Iran and its history goes back to 6-5 decades. Transformations ofthe world, especially domestic developments of world capitalism in the 60s and desire to access new markets consumption in addition to political, economic, social situation and especially the collapse of landlordism are such causes of its creation. Some items such as High oil prices, the formation of single-product economy based on oil, land reform and change in ownership of agricultural lands, money economic alternative with old feudalism, lack of energy and lack of suitable development model, planning approach, more and more disrupting the space balance To disrupt the rural management system and the lack of appropriate alternatives for it and ..... must be added to the mentioned items. Urban poverty is one of the factors that influence the spread of Suburbanization that in addition to sever rural-Urban migration throws poor urban residents to the suburbs and in opposite direction of the logic rhythm of development and urban management it creates social, economic, cultural, political and security challenges and problems (Khajeh Delooei 2004).In our country, there is a close relationship between population growth especially urban population, structural changes in the economy, inability of the government in providing housing and population residing and living in the phenomenon of Suburbanization. Investigation of demographic trends in the country reveals this issue( Rahnama and Tavangar95:2008). What is clear is that suburbanization and low-income groups of urban settlements around metropolises of our country is the improper manifestation of urban poverty and performance of space as the reproduction of poverty (Khatam61:2003)

\section{INFORMAL SETTLEMENTS IN TEHRAN}

Tehran's population growth from 1345 onwards very fast. Annual growth rate of this city between years $1975-76$ has been equal to $2.5 \%$. About 1082 thousand people have been raise to the number of population during the same decade. Tehran's population has almost doubled from 1975-76 with the growing trend and the size of the city at this time tripled. Sharp increase in population during 1976 and after that was due to irregular and severe migration to Tehran (Mashhadizadeh Dahaghani321:2003). Need for housing and urban services and land prices were rise greatly with uneven and lopsided increase in population of Tehran and in particular the formation of bands of intense immigration after in 1976 decade. Poor immigrants trying to find shelter for residence turned inside and outside the city. Many deployed behind the city gates and settled in unplanned towns. Absence of a coordinated strategy between the government and urban management is the primary reason that an urban expert will express about the exponential growth of population of metropolitans and development of informal settlements (Namazikhah, 2006: 42). While the pace of the physical growth of metropolis of Tehran prevented appropriate develop and implement and proper to organizing programs of margins of city and make urban management system forced to short-term fix problems caused by widespread marginalization. Method of Tehran Municipality actions in rebuilding the slums:

1. Purchasing and demolition of slums and transmitting resettlement to government complexes or lending loan, land gratuitous helps for housing(eg: Area in South of Tehran).

2. Destruction of slums transmitting resettlement to government complexes (such as Shahrara huts and railway).

3. Destruction of huts and firing residents, without any effective protection measures (Such slums located in 15 municipality of Tehran).

4. Recognition of slums and efforts to improve its environment (such as Khaksefid in Tehranpars). It is worth noting that recent encounter with the inhabitants of Khaksefid like clause 3.

5. Efforts to improve the environment of slums without recognition(such as Shahid Motahhari and huts of Yousefabad) (Saeidnia, 1383: 122). 


\section{HYPOTHESES}

1. Immigration is the cause of the formation of the slum in the city of Tehran.

2. Easier access to providing housing is the cause of the formation of the slum in the city of Tehran.

3. Low income of individuals is the cause of the formation of the slum in the city of Tehran.

4. High rental housing is the cause of the formation of the slum in the city of Tehran.

\section{RESEARCH METHODOLOGY}

This research method is survey and documents method. Statistical population consists of resident in marginal neighborhoods. The sample size was determined using a Cochran of 200 households that distributing the questionnaire was conducted randomly. Independent variables include immigration, low income, high rent of housing and easier way of providing housing and suburbanization is the dependent variable. After collecting data with questionnaire and data processing with Spss software, inferential descriptive statistics and chi-square statistics were used according to the level of measurement of variables.

\section{DESCRIPTIVE FINDINGS}

According to the results obtained, about the characteristics of the studied sample, $85 \%$ of respondents talk in Persian and 14\% talk in Turkish and 1\% talk in Arabic language. About education, the 8\% were illiterate, $37 \%$ primary education, $31 \%$ cycle and only $11 \%$ have university degree. In terms of employment, $13 \%$ are unemployed, $4 \%$ in the public sector, $21 \%$ in the private sector, $57 \%$ are selfemployed and 5\% are retired. In terms of income, one percent less than fifty thousand toman , $13 \%$ between 50 and 200 thousand toman,49\% between $200-350$ thousand and 28\% higher than 350 thousand toman have earned, $59 \%$ of respondents are within the Tehran that migrated from around cities and villages to these areas and $41 \%$ of respondents are from out of Tehran(mostly from western and north cities ) $.54 \%$ are low satisfied with their place of living, $38 \%$ moderately are satisfied and $8 \%$ are highly satisfied. According to table (1),17\% of respondent have pointed to appropriate job market in Tehran as the most effective factor for living in Tehran. In contrast, each factor of low rent and low cost of housing and facilities and comforting services 3\%, closeness to the relatives $6 \%$ and other factors $12 \%$ are the factors that are effective in selecting Tehran for place of living.

Table 1: Tehran Attractions factors

\begin{tabular}{|l|l}
\hline Percent of all & Items \\
\hline 17 & Labor markets and employment \\
\hline 3 & The low price of rent of ground and land \\
\hline 3 & Facilities and welfare services \\
\hline 6 & Proximity to relatives \\
\hline 12 & other items \\
\hline 59 & The indigenous inhabitants of Tehran \\
\hline 100 & total \\
\hline
\end{tabular}

Table 2 inhibiting factors of the last place of living

\begin{tabular}{|c|c|c|}
\hline Percent of all & Items & \\
\hline 26 & $\begin{array}{l}\text { High prices of land and } \\
\text { housing }\end{array}$ & \multirow{6}{*}{$\begin{array}{l}\mathscr{0} \\
\tilde{0} \\
\tilde{\mathscr{E}} \\
\simeq\end{array}$} \\
\hline 17 & High housing rents & \\
\hline 4 & Being Away from work & \\
\hline 5 & Being Away from relatives & \\
\hline 2 & All items & \\
\hline 10 & With their families & \\
\hline
\end{tabular}




\begin{tabular}{|c|l}
\hline 36 & Not mentioned \\
\hline 100 & total \\
\hline
\end{tabular}

Tale 2 is related to the reason of choosing place of living, as it is observed, during selecting the place of living ,the economic factor does not only play an essential role in cost of land, house and amount of rent ,it also has an effect of the situation of housing to the place of work, general services and...

Low price of land and housing is mentioned as the most important factor by respondent .(45)\% has significant role in selecting the place of living .3\% low price of housing rent ,5\% closeness to the work place, $6 \%$ being close to the relatives, $5 \%$ are other factors that lead to attract immigrants to these areas.

Table (3): reason of selecting current place for living

\begin{tabular}{|l|l}
\hline $\begin{array}{l}\text { Percent of } \\
\text { all }\end{array}$ & Items \\
\hline 44 & Inexpensive land and house \\
\hline 3 & The low rent of housing \\
\hline 5 & Being close to work \\
\hline 6 & Proximity to relatives \\
\hline 5 & other items \\
\hline 37 & Not mentioned \\
\hline 100 & total \\
\hline
\end{tabular}

\section{ANALYTICAL FINDINGS}

Hypothesis 1: Immigration is the cause of the formation of the slum in the city of Tehran

Obtained results indicates there is significant relationship $r$ between this variable and suburbanization indicate with level of significance (0.000) and coefficient 135.5 .Obtained result of coefficient cheesquare has been observed in table (4) .

Table (4) the correlation coefficient between suburbanization and immigration

\begin{tabular}{|r|l|l|l|}
\hline Significance & $\begin{array}{l}\text { Degrees } \\
\text { of } \\
\text { freedom }\end{array}$ & Rate & $\begin{array}{l}\text { The correlation } \\
\text { coefficient }\end{array}$ \\
\hline $0 / 000$ & 4 & $135 / 5$ & Chi-square \\
\hline
\end{tabular}

Hypothesis 2: Easier access to providing housing is the cause of the formation of the slum in the city of Tehran.

According to the table (5) with coefficient 168.38 and level of significance, less than 0.5 indicate the confirmation of hypothesis and the relationship between these two variables. .

Table (5) the correlation coefficient between easy providing of house and suburbanization

\begin{tabular}{|r|rr|r|r|}
\hline Significance & $\begin{array}{l}\text { Degrees of } \\
\text { freedom }\end{array}$ & Rate & $\begin{array}{l}\text { The correlation } \\
\text { coefficient }\end{array}$ \\
\hline $0 / 000$ & & 4 & $186 / 381$ & Chi-square \\
\hline
\end{tabular}

Hypothesis 3: Low income of individuals is the cause of the formation of the slum in the city of Tehran

As it observed in table (6) there is a significant relationship between two variables using Chi-square, coefficient of 19.8 and level of significance $(0.000)$ 
Table (6) the correlation coefficient between low income and suburbanization

\begin{tabular}{|r|l|c|l|}
\hline Significance & $\begin{array}{l}\text { Degrees } \\
\text { of } \\
\text { freedom }\end{array}$ & Rate & $\begin{array}{l}\text { The correlation } \\
\text { coefficient }\end{array}$ \\
\hline $0 / 000$ & 3 & $19 / 878$ & Chi-square \\
\hline
\end{tabular}

1. Hypothesis 4: High rental housing is the cause of the formation of the slum in the city of Tehran.

2.

There is a significant relationship between two variables, using Chi-square with coefficient of 74.71 and degree of freedom 5 and level of significance that is less than 0.5.Tend to suburbanization area will be increase by the increase of the amount of rent (table 7)

Table (7) the correlation coefficient between high amount of rent and suburbanization

\begin{tabular}{|c|l|l|l|}
\hline Significance & $\begin{array}{l}\text { Degrees } \\
\text { of } \\
\text { freedom }\end{array}$ & Rate & $\begin{array}{l}\text { The correlation } \\
\text { coefficient }\end{array}$ \\
\hline $0 / 000$ & 5 & $74 / 714$ & Chi-square \\
\hline
\end{tabular}

\section{CONCLUSION}

The consequence of rapid urbanization in Iran, is the emergence of large cities and marginalized areas with abnormal texture and abnormal housing. Tehran is not deprived from this phenomenon. This study was tried to investigate the main factors of suburbanization forming in Tehran. Suburbanization has been considered as dependent variable and easy providing housing, high rent, immigration and income have been considered as independent variable. Result of the hypothesis show that there is a significant relationship between independent variables and dependent variable means suburbanization. According to the obtained result of this study, it can be possible to prevent the extension of suburbanization through controlling these factors in short term and long term planning of development and stop them using fair distribution of facilities in all city. For sure the effective role of government in creating and improving and decreasing or increasing the state of suburbanization, fair distribution of educational ,job and health facilities, creating and establishing cultural and entertainment places and... must not be forgotten. Government must try to have appropriate and deep knowledge of their structure to organize these areas and in the next step help them to their gradual exiting of these areas from the usual form to the appropriate form through making cooperative policies and based on mutual trust using intelligent supports with aim of meeting their need with the priority that determines from suburbanization.

\section{REFRENCES}

Athaari,Kamal(2002) Justice in space, Journal of Seven Cities, ninth and tenth No

Aubrey, S. (1991), migration, urbanization and development, translated by: Farhang Ershad, Publications of the Institute of Labor and Social Security

Papeli Yazdi,Mohammadhosein and Hosein Rajabi Sanajerdi(2004) Theory of the city and its surroundings, Samt Publication

Piran,Parviz(1994) Slums in Iran, political-economic magazine Information, No. 88-87, Institute of Information..

Taghavai,Nematallah(1998) ) Rural Sociology, University of Payam Noor publication

Todaro, Michael (1987) economic development in the Third World, the first volume, translated by Gholam Ali Farjadi, publication of and development program.

Hesamian,Farrokh and others(2009) Urbanization in Iran, seventh vol, Aagah Publications

Hataminejad,Hosein and Mohammadjafar Zomorodian(2002) Informal settlement in Mashhad, municipalities Magazine, fourth year Issue 45.

Khajeh Deloee,Manoochehr(2004)( Deputy Minister of Housing and Urban Development), television program interview 
Khatam,Azam(2003) Suburbia and informal settlements in Tehran, the chances of social integration, Proceedings of suburbia and informal settlements, Social Welfare and Rehabilitation Sciences University

Khabbaz Beheshti,Zahra(2001)immigration : Investigating the problems of migrants in the world, books hangar publishing.

Khoobayand.Saeed(2005) Spatial analysis of causes of the formation of squatters in Isfahan, Ph.D. dissertation, University of Isfahan.

.Rabbani,Rasoul et al(2006) Factors affecting the formation of the suburbanization and social consequences in the city of Ahvaz, the Journal of Geography and Development, No. 4, pp89-114

Rahnama,Mohammadahim and Masoumeh Tavangar(2008) A comparative study of suburbanization in the cities of Sabzevar, Neishabour and Torbat Heydarieh GONABAD, Journal of Geography and Regional Development, eleventh number

Zahedani,Saeed(2001) Suburbanization, Second Edition, University of Shiraz Publications

Saeednia.Ahmad(2004) System of urban centers and residential spaces, Green Book of Guide to municipalities, municipal organizations publications

Shookooei ,Hosein(1986)cities socio system and residential spaces, Green guide of municipalities, municipal organizations publication

Shookooei ,Hosein(1990) cities socio system and residential spaces, Green guide of municipalities,Second print. ACECR the central office Publications.

Sheibani,Maliheh(2005) Poverty, deprivation and citizens in Iran, Journal of Social Welfare, fifth year,Issue 18, pp64-41.

Sheikhi,Mohammad(2001) Explaining the process of the formation and transformation of settlements of car surrounding metropolis of Tehran,case study :Islam Shahr,Akbarabad and SoltanAbad, PhD dissertation, Tehran University

Sarrafi,Mozaffar(2002) Towards the theory for informal settlements. Urbanization to suburbia text, Journal of seven cities, third cities, Issue VIII.

Findeli,Sel(1993) Internal migration planning, translated by Abdul Ali Lahsaeizadeh, Navid Publications

Fakoohi,Naser(2004) Urban Anthropology, First Edition, Ney publication

Gilbert, Allen and Gallagher, Joseph (1996) cities,translated by Parviz Karim Naeri, Public Relations

Department and international Tehran Municipality Publications.

Mashhadizade dahaghani,Naser(2003) Bio-physical diversity of settlement surrounding the city of Tehran, proceedings of suburbia and informal settlements, the first volume, University of Social Welfare and Rehabilitation Sciences.

Momtaz,Farideh(2004) Sociology of the city .Publishing Corporation Press

Hadizadeh Bazzaz,Maryam(2003) Mareditginalization and organizing strategies in the world,first edition., Mashhad Municipality publication in cooperation with Tiho publication.

Namazikhah,Zahra(2006) news site of tomorrow city . Monday, Persian date Azar 20

Fly,\& Others(2005): Environmental Health Project, Activity Report 109, Health of Children Living in urban Slums in Asia \& The Near East.

Coit, K. (1994) Self - Help Housing for The Poor, A Cross, Cultural Study, Cities, No 11.

Lewis, Oscar. (1998) the Culture of Poverty, Society, Vol. 35 No. 2, 7-30.

Lewis, G.J. (1982). Human Migration, Croon Helm, London.

Macedo, J (2000), Land use Policies and Urbanization of Formal Settlement. Planning Imitative for Environmental Protection Areas in Curitiba, Brazil. Dissertation PH.D, Advisor: Stroh, Robert C. University of Florida: United States.

Park, Robert, E. (1967) The City Suggestion for the Investigation of Human Behavior in Urban Environment, Chicago University Press.

Srivinas, H (2004), Defining Squatter Settlement. http://www.Gdrc.org/uem/ defines- squatter.html 